\title{
THE GROWTH AND FLOWERING OF Hyacinthus orientalis L. FORCED IN POTS UNDER FLUORESCENT LIGHT OF DIFFERENT COLOURS
}

\author{
Małgorzata Śmigielska, Marek Jerzy, Agnieszka Krzymińska \\ Department of Ornamental Plants, Poznań University of Life Sciences \\ Dąbrowskiego 159, 60-594 Poznań, Poland \\ e-mail: akrzym@up.poznan.pl
}

Received: 26.09.2013

\begin{abstract}
Three hyacinth cultivars were forced under fluorescent lamps which emitted white, blue, green, yellow and red light. The plants started flowering in the first decade of February. The forcing period for two cultivars, 'Anna Marie' and 'Blue Star', was shortest under lamps emitting red light. The cultivar 'White Pearl' flowered equally early under lamps emitting red, white and blue light. The impact of light colour (wavelength) on the leaf greenness index (SPAD) was demonstrated. The photosynthetic activity of leaves was dependent on the cultivar. It was related both to the net rate of photosynthesis and the photosynthetic efficiency. Specific leaf area (SLA) also depended on the cultivar. The level of SLA was related to the rate of photosynthesis and its efficiency. SLA was highest in all cultivars under green and yellow colour light. The chlorophyll content in the fresh and dry weight of leaves was highest under yellow light lamps.
\end{abstract}

Key words: Hyacinthus orientalis L., forcing in winter, leaves, photosynthetic activity

\section{INTRODUCTION}

Bulbous plants are very popular in Poland in winter time. Their production is run in moderately warm greenhouses, plastic tunnels or, more often, in closed spaces such as warehouses and cellars under artificial light. Production under such conditions is possible as these plants have low light requirements. This is due to the fact that bulbs accumulate enough nutrients which are indispensable in the process of plant development. However, depending on the species, these requirements differ in regard to the photoperiod and light intensity $[1,2,3,4]$.
Simultaneously, investigations were conducted on the influence of light colour on both the time of flowering and the quality of forced plants $[5,6,7,8]$. Krzymińska [9] stated that forcing alliums depends on the species, cultivar and method of bulb cooling. Wet-cooling of bulbs at a temperature of $9^{\circ} \mathrm{C}-2^{\circ} \mathrm{C}$ promotes production of a larger number of flowering plants with longer inflorescence peduncles and within a shorter period of time than after cooling of bulbs by means of the standard (dry) method at the same temperature. Alliums forced for cut flowers, cooled for 18 weeks, bloom earlier and their inflorescence peduncles are longer than in alliums flowering after a shorter bulb cooling period. The largest percentage of flowering plants is obtained when bulbs are wet-cooled for 16 and 18 weeks.

Little is known about the possibility of forcing hyacinths under artificial light $[10,11,12,13]$. Based on the research conducted by S mi g i e l s k a and J e r z y [12], it is apparent that post-harvest longevity of hyacinths depends on, among other things, the length of the flowering period, which in turn is the longest after the application of white and blue light. Red light, on the other hand, reduces post-harvest longevity of flowers and diminishes their ornamental value. The stiffness of flower shoots depends on the cultivar, but it is still considerably lower than that recommended for plants flowering in pots intended for sale. The same is also applicable to leaves, whose elongation is the highest under lamps emitting red light. In cv. 'Fondant', this elongation caused maximal flabbiness of inflorescence shoots and leaves. Other experiments by Śmigielska and Jerzy [13] revealed that hyacinths flower earliest under blue and red fluorescent light. Plants forced under lamps emitting red light form 
longer inflorescences and are flabbier. Plants forced under lamps emitting blue light are slightly lower than others and have shorter leaves. In the described experiment, two daily light dose treatments were applied: in the first one, quantum irradiance was $12.5 \mu \mathrm{mol} \times$ $\mathrm{m}^{-2} \times \mathrm{s}^{-1}$ and the photoperiod was $12 \mathrm{~h}$; in the other one, quantum irradiance was $25 \mu \mathrm{mol} \times \mathrm{m}^{-2} \times \mathrm{s}^{-1}$ and the photoperiod was $6 \mathrm{~h}$, which in each treatment was equal to quantum irradiance of $0.54 \mathrm{~mol} \times \mathrm{m}^{-2}$. It was found that the dosage of light has no effect either on the date of flowering or plant quality.

The purpose of the conducted experiment was to establish the effect of fluorescent light colour on growth and flowering of hyacinths forced in pots. The photosynthetic activity of leaves and the chlorophyll content in fresh and dry leaf weight were analysed.

\section{MATERIALS AND METHODS}

The experiment involved three cultivars of $\mathrm{Hya}$ cinthus orientalis L.: 'Anna Marie', 'Blue Star', and 'White Pearl'.

The bulb cooling process at a temperature of $+9^{\circ} \mathrm{C}$ was commenced on 17 October 2011. Prior to cooling, bulbs with a circumference of 19-20 cm were planted in $11 \mathrm{~cm}$ diameter pots, in a medium which consisted of a mixture of high moor peat and sand (4:1). After 12 weeks the pots with bulbs were moved to the growth room and on 16 January 2012 plant forcing began. The plants were forced under artificial light. The sources of light were fluorescent Philips TLD 36 W lamps: White Colour 33 (370-700 nm), Blue Colour 18 (480-580 nm), Green Colour 17 (360-630 nm), Yellow Colour $16(500-650 \mathrm{~nm})$ and Red Colour 15 $(600-700 \mathrm{~nm})$. The photosynthetic activity of leaves was measured under daylight colour lamps - Daylight Colour 54 (370-700 nm). Quantum irradiance was 12.5 $\mu \mathrm{mol} \times \mathrm{m}^{-2} \times \mathrm{s}^{-1}$ and the photoperiod was $6 \mathrm{~h} \times \mathrm{d}^{-1}$. Air temperature in the growth room was $17 \pm 1^{\circ} \mathrm{C}$ and relative humidity was between $64-70 \%$. The spectral characteristics of the fluorescent lamps determined using a spectroradiometer (USB 4000) are shown in Figure 1.

The experiment comprised 15 combinations (light colour x cultivar) of 10 replications, each of which consisted of one plant.

The length of the forcing period was calculated. The date of appearance of the first flower at the bottom of the inflorescence was the indicator of the beginning of the blooming period. On that day, the height of plants, the length of the longest leaf and of the inflorescence, and the diameter of plants were determined based on two measurements (at the widest and narrowest point of the plant). Afterwards, the means were calculated. The leaf greenness index (SPAD) was meas- ured using a Yara N-Tester apparatus. In order to do so, the leaves from the outer whorl of each plant were measured three times and the means were calculated.

The photosynthetic activity of hyacinth leaves is unknown. This parameter was examined for plants forced under white colour light. The photosynthetic activity of leaves was examined using a portable CI-340aa apparatus (CID Biosciences Inc, USA) in the initial phase of plant flowering. For this purpose, fully developed leaves with no signs of senescence or mechanical damage were selected. In order to avoid the influence of the external factors on the rate of photosynthesis, the leaves were placed in a measuring compartment. The conditions in the measuring compartment were as follows: constant concentration of carbon dioxide (330 $\mu \mathrm{mol} \mathrm{CO} \mathrm{CO}_{2} \times \mathrm{mol}^{-1}$ of the air), constant rate of photosynthetic active radiation $\left(1,000 \mu \mathrm{mol} \times \mathrm{m}^{-2} \times \mathrm{s}^{-1}\right)$, and constant temperature $\left(30^{\circ} \mathrm{C}\right)$. The following measurements of the parameters were taken: net photosynthetic rate, stomatal conductance, efficiency of photosynthesis, and the leaf transpiration index.

The contents of chlorophyll $a+b$, chlorophyll a and $b$ in fresh weight of leaves were determined by means of dimethyl sulfoxide extraction (DMSO). Five plants were randomly selected from each combination. For this purpose, $0.2 \mathrm{~g}$ of a fresh leaf was ground and then placed in a test-tube into which $5 \mathrm{ml}$ of $95 \%$ dimethyl sulfoxide was added. The test-tubes were nect placed in a water bath at a temperature of $60-70^{\circ} \mathrm{C}$ in order to extract chlorophyll from the leaves. The spectrophotometric analysis of the extracts was conducted under three wavelengths: 645, 652 and $663 \mathrm{~nm}$. The contents of chlorophyll $\mathrm{a}+\mathrm{b}$, chlorophyll $\mathrm{a}$ and $\mathrm{b}$ in leaf fresh weight were calculated using Arnon's equation [14].

In order to determine the chlorophyll content in leaf dry weight, sample leaves were dried to constant weight at $105^{\circ} \mathrm{C}$ to provide the percentage of leaf dry matter. Then, the chlorophyll content was calculated according to the following formula: $[1 /(\%$ dry weight/100)] chlorophyll content in fresh weight of leaves.

Specific leaf area (SLA) was determined as the ratio of leaf blade surface area and leaf dry matter [15]. The leaf surface area was measured using the CI-202 apparatus (CID Bio-sciences Inc, USA) and laboratory scales. Five plants were randomly selected from each combination. The results were put into the following formula: $\{[($ fresh matter $\cdot$ dry matter $) / 100] /$ leaf surface $\} \cdot 1,000$.

The results were analysed statistically using the analysis of variance (ANOVA) separately for each cultivar, where the significance of differences was assessed with Duncan's test at $\alpha=0.05$. 

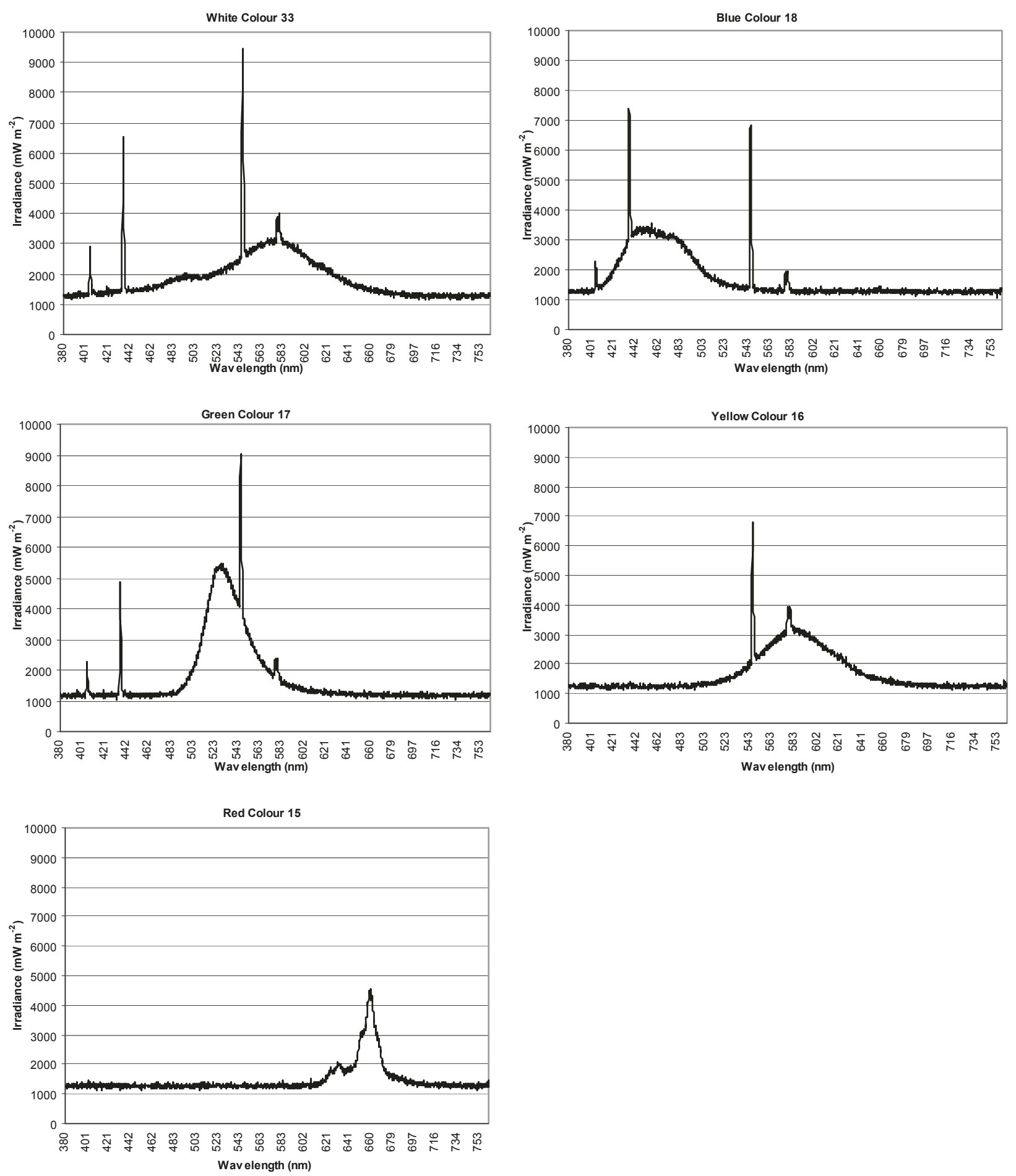

Fig. 1. Spectral characteristics of the fluorescent lamps Philips TLD 36 W.

\section{RESULTS}

The plants started flowering in the first decade of February (Table 1). The forcing period of two hyacinth cultivars, i.e. 'Anna Marie' and 'Blue Star', was shortest under red light lamps. The cultivar 'White Pearl' bloomed as early under white and blue light lamps as it did under red light lamps. The influence of light colour on plant height in cv. 'Anna Marie' and 'Blue Star' was insignificant. However, cv. 'White Pearl' did form the longest inflorescences under green and yellow light lamps, but the recorded results did not differ significantly from the height obtained under white and blue colour lamps. 
Table 1

Effect of fluorescent light colour on growth and flowering of three hyacinth cultivars

\begin{tabular}{|c|c|c|c|c|c|}
\hline \multirow{2}{*}{ Features of plants ready for harvest } & \multicolumn{5}{|c|}{ Light colour } \\
\hline & White & Blue & Green & Yellow & Red \\
\hline \multicolumn{6}{|c|}{ 'Anna Marie' } \\
\hline Forcing period (days) & $25.7 b^{1}$ & $25.7 \mathrm{~b}$ & $26.0 \mathrm{~b}$ & $25.6 \mathrm{~b}$ & $23.7 \mathrm{a}$ \\
\hline Plant height (cm) & $23.2 \mathrm{a}$ & $23.2 \mathrm{a}$ & $24.7 \mathrm{a}$ & $22.9 \mathrm{a}$ & $23.9 \mathrm{a}$ \\
\hline Inflorescence length (cm) & $8.7 \mathrm{a}$ & $8.7 \mathrm{a}$ & $8.6 \mathrm{a}$ & $8.9 \mathrm{a}$ & $8.9 \mathrm{a}$ \\
\hline Length of the longest leaf $(\mathrm{cm})$ & $24.3 \mathrm{a}$ & $26.4 \mathrm{ab}$ & $27.9 \mathrm{~b}$ & $28.4 \mathrm{~b}$ & $27.9 \mathrm{~b}$ \\
\hline Plant circumference $(\mathrm{cm})$ & 8.9 a & $8.5 \mathrm{a}$ & $9.4 \mathrm{a}$ & $9.4 \mathrm{a}$ & $8.7 \mathrm{a}$ \\
\hline $\mathrm{SPAD}^{2}$ & $56.7 \mathrm{~b}$ & $51.1 \mathrm{a}$ & $53.2 \mathrm{ab}$ & $57.9 \mathrm{~b}$ & $55.6 \mathrm{~b}$ \\
\hline $\mathrm{SLA}^{3}$ & $58.1 \mathrm{a}$ & $65.8 \mathrm{ab}$ & $78.2 \mathrm{~b}$ & $79.7 \mathrm{~b}$ & $58.0 \mathrm{a}$ \\
\hline \multicolumn{6}{|c|}{ 'Blue Star' } \\
\hline Forcing period (days) & $28.9 \mathrm{~b}$ & $28.9 \mathrm{~b}$ & $27.7 \mathrm{~b}$ & $28.9 \mathrm{~b}$ & $25.9 \mathrm{a}$ \\
\hline Plant height $(\mathrm{cm})$ & $20.5 \mathrm{a}$ & $21.1 \mathrm{a}$ & $21.5 \mathrm{a}$ & $20.8 \mathrm{a}$ & $20.4 \mathrm{a}$ \\
\hline Inflorescence length (cm) & $9.5 \mathrm{a}$ & $9.3 \mathrm{a}$ & $9.1 \mathrm{a}$ & $9.1 \mathrm{a}$ & $9.4 \mathrm{a}$ \\
\hline Length of the longest leaf $(\mathrm{cm})$ & $18.1 \mathrm{a}$ & $18.4 \mathrm{a}$ & $18.4 \mathrm{a}$ & $17.6 \mathrm{a}$ & $18.7 \mathrm{a}$ \\
\hline Plant circumference $(\mathrm{cm})$ & $5.9 \mathrm{a}$ & $6.3 \mathrm{a}$ & $5.6 \mathrm{a}$ & $6.4 \mathrm{a}$ & $6.1 \mathrm{a}$ \\
\hline SPAD & $59.5 \mathrm{~b}$ & $55.0 \mathrm{a}$ & $57.9 \mathrm{ab}$ & $58.5 \mathrm{~b}$ & $55.5 \mathrm{a}$ \\
\hline SLA & $19.0 \mathrm{a}$ & $20.7 \mathrm{a}$ & $23.6 \mathrm{~b}$ & $22.2 \mathrm{~b}$ & $20.9 \mathrm{a}$ \\
\hline \multicolumn{6}{|c|}{ 'White Pearl' } \\
\hline Forcing period (days) & $27.4 \mathrm{a}$ & $27.0 \mathrm{a}$ & $29.9 \mathrm{~b}$ & $29.4 \mathrm{~b}$ & $26.0 \mathrm{a}$ \\
\hline Plant height (cm) & $18.3 \mathrm{ab}$ & $18.6 \mathrm{ab}$ & $21.5 \mathrm{~b}$ & $20.1 \mathrm{~b}$ & $18.0 \mathrm{a}$ \\
\hline Inflorescence length (cm) & $9.8 \mathrm{a}$ & $10.2 \mathrm{a}$ & $9.7 \mathrm{a}$ & $10.0 \mathrm{a}$ & $11.1 \mathrm{~b}$ \\
\hline Length of the longest leaf $(\mathrm{cm})$ & $13.9 \mathrm{a}$ & $14.8 \mathrm{a}$ & $17.4 \mathrm{~b}$ & $18.2 \mathrm{~b}$ & $18.3 \mathrm{~b}$ \\
\hline Plant circumference $(\mathrm{cm})$ & $7.3 \mathrm{a}$ & $7.5 \mathrm{a}$ & $7.8 \mathrm{a}$ & $7.5 \mathrm{a}$ & $8.0 \mathrm{a}$ \\
\hline SPAD & $54.5 \mathrm{c}$ & $46.3 \mathrm{a}$ & $51.3 \mathrm{~b}$ & $55.5 \mathrm{c}$ & $52.4 \mathrm{~b}$ \\
\hline SLA & $12.9 \mathrm{a}$ & $14.4 \mathrm{a}$ & $16.9 \mathrm{~b}$ & $16.6 \mathrm{~b}$ & $13.9 \mathrm{a}$ \\
\hline
\end{tabular}

${ }^{1}$ Means followed by the same letters do not differ significantly at $\alpha=0.05$

${ }^{2} \mathrm{SPAD}$ - Leaf greenness index

${ }^{3}$ SLA - Specific leaf area

Light colour was found to have no effect on inflorescence length produced by cv. 'Anna Marie' and 'Blue Star'. In contrast, cv. 'White Pearl' formed the longest inflorescences under red light lamps.

The length of the longest leaf in cv. 'Blue Star' was not dependent on light colour. On the other hand, the influence of light colour was observed in cv. 'Anna Marie' and 'Blue Star' which formed shorter leaves under white and blue light lamps than under green, yellow and red light lamps.

Light colour had no effect on plant diameter in any of the three studied cultivars of Hyacinthus orientalis. However, the effect of fluorescent light colour on the leaf greenness index (SPAD) was observed. Under white and yellow light lamps, the index was the highest. It was also of the highest value under red light lamps in cv. 'Anna Marie. The recorded values did not differ significantly from those obtained under green light lamps in cv. 'Anna Marie' and 'Blue Star'.
Specific leaf area (SLA) was highly dependent on the cultivar. The highest value of SLA was observed in cv. 'Anna Marie', while it was lowest in cv. 'White Pearl'; the average index value was observed in cv. 'Blue Star'. SLA values were highly dependent on fluorescent light colour and were highest in all the cultivars under green and yellow light. The SLA values recorded in cv. 'Anna Marie' did not differ significantly from those obtained under blue light lamps.

A comprehensive comparison of the mean values calculated for light colour of the three studied cultivars of Hyacinthus orientalis leads to the conclusion that fluorescent light colour has a significant effect on growth and flowering of these cultivars forced in pots (Table 2). Nonetheless, light colour was not shown to have an effect on plant diameter and inflorescence length. 
Table 2

Mean values of features calculated for light colour in three studied hyacinth cultivars

\begin{tabular}{|c|c|c|c|c|c|}
\hline \multirow{2}{*}{ Plant features } & \multicolumn{5}{|c|}{ Light colour } \\
\hline & White & Blue & Green & Yellow & Red \\
\hline Forcing period (days) & $27.3 b^{1}$ & $27.2 \mathrm{~b}$ & $27.9 \mathrm{~b}$ & $28.0 \mathrm{~b}$ & $25.2 \mathrm{a}$ \\
\hline Plant height $(\mathrm{cm})$ & $20.7 \mathrm{a}$ & $21.0 \mathrm{a}$ & $22.6 \mathrm{~b}$ & $21.3 \mathrm{a}$ & $20.8 \mathrm{a}$ \\
\hline Inflorescence length (cm) & $9.3 \mathrm{a}$ & $9.4 \mathrm{a}$ & $9.1 \mathrm{a}$ & $9.3 \mathrm{a}$ & $9.8 \mathrm{a}$ \\
\hline Length of the longest leaf $(\mathrm{cm})$ & $18.8 \mathrm{a}$ & $19.9 \mathrm{a}$ & $21.4 \mathrm{~b}$ & $21.4 \mathrm{~b}$ & $21.6 \mathrm{~b}$ \\
\hline Plant circumference $(\mathrm{cm})$ & $7.4 \mathrm{a}$ & $7.4 \mathrm{a}$ & $7.6 \mathrm{a}$ & $7.8 \mathrm{a}$ & $7.6 \mathrm{a}$ \\
\hline $\mathrm{SPAD}^{2}$ & $56.9 \mathrm{c}$ & $50.8 \mathrm{a}$ & $54.1 \mathrm{~b}$ & $57.3 \mathrm{c}$ & $54.5 \mathrm{~b}$ \\
\hline
\end{tabular}

${ }^{1}$ Means followed by the same letters do not differ significantly at $\alpha=0.05$

${ }^{2} \mathrm{SPAD}$ - Leaf greenness index

The photosynthetic activity of leaves was dependent on the cultivar (Table 3 ). It concerns both the net photosynthetic rate and its efficiency as well as stomatal conductance. The efficiency of photosynthesis, resulting from its intensity and stomatal conductance, was the highest in cv. 'Anna Marie' and the lowest in cv. 'White Pearl'. In cv. 'Blue Star', the efficiency of photosynthesis was moderate.
Leaf transpiration did not depend significantly on the cultivar. The differences observed in the different cultivars were insignificant and may be disregarded.

Chlorophyll content in leaf fresh matter in hyacinths forced in pots under artificial light was dependent on light colour and the cultivar (Table 4). Under fluorescent yellow light, the contents of chlorophyll a, b as well as of $a+b$ were the highest in all the selected cultivars.

Table 3

Leaf photosynthetic activity of three hyacinth cultivars forced in pots under fluorescent lamps emitting daylight colour

\begin{tabular}{lccc}
\hline \multicolumn{1}{c}{ Parameters of leaf photosynthetic activity } & \multicolumn{2}{c}{ Cultivar } \\
\cline { 2 - 4 } & Anna Marie & Blue Star & White Pearl \\
\hline Net photosynthetic rate $\left(\mu \mathrm{mol} \mathrm{CO} \mathrm{m}^{-2} \times \mathrm{s}^{-1}\right)$ & $5.16 \mathrm{c}^{1}$ & $4.15 \mathrm{~b}$ & $3.17 \mathrm{a}$ \\
Stomatal conductance $\left(\mathrm{mmol} \times \mathrm{m}^{-2} \cdot \mathrm{s}^{-1}\right)$ & $10.74 \mathrm{c}$ & $10.11 \mathrm{~b}$ & $9.84 \mathrm{a}$ \\
Photosynthesis efficiency $\left(\mu \mathrm{mol} \mathrm{CO} \mathrm{m}^{-2} \times \mathrm{s}^{-1} / \mathrm{mmol} \times \mathrm{m}^{-2} \times \mathrm{s}^{-1}\right)$ & $0.52 \mathrm{c}$ & $0.41 \mathrm{~b}$ & $0.32 \mathrm{a}$ \\
Transpiration rate $\left(\mathrm{mmol} \mathrm{H} \mathrm{O} \mathrm{m}^{-2} \times \mathrm{s}^{-1}\right)$ & $0.20 \mathrm{a}$ & $0.19 \mathrm{a}$ & $0.18 \mathrm{a}$ \\
\hline
\end{tabular}

${ }^{1}$ Means followed by the same letters do not differ significantly at $\alpha=0.05$

Table 4

Effect of fluorescent light colour on chlorophyll content in leaf fresh weight of three hyacinth cultivars

\begin{tabular}{|c|c|c|c|c|c|}
\hline \multirow{2}{*}{$\begin{array}{l}\text { Chlorophyll content in leaf } \\
\text { fresh weight } \\
\left(\mathrm{mg} \times \mathrm{g}^{-1}\right)\end{array}$} & \multicolumn{5}{|c|}{ Light colour } \\
\hline & White & Blue & Green & Yellow & Red \\
\hline \multicolumn{6}{|c|}{ 'Anna Marie' } \\
\hline Chlorophyll a & $0.26 \mathrm{a}^{1}$ & $0.30 \mathrm{~b}$ & $0.31 \mathrm{~b}$ & $0.38 \mathrm{c}$ & $0.24 \mathrm{a}$ \\
\hline Chlorophyll b & $0.07 \mathrm{a}$ & $0.09 \mathrm{~b}$ & $0.09 \mathrm{~b}$ & $0.12 \mathrm{c}$ & $0.06 \mathrm{a}$ \\
\hline Chlorophyll a+b & $0.31 \mathrm{a}$ & $0.40 \mathrm{~b}$ & $0.39 \mathrm{~b}$ & $0.49 \mathrm{c}$ & $0.29 \mathrm{a}$ \\
\hline \multicolumn{6}{|c|}{ 'Blue Star' } \\
\hline Chlorophyll a & $0.49 \mathrm{~b}$ & $0.44 \mathrm{ab}$ & $0.38 \mathrm{a}$ & $0.58 \mathrm{c}$ & $0.51 \mathrm{~b}$ \\
\hline Chlorophyll b & $0.19 \mathrm{~b}$ & $0.15 \mathrm{~b}$ & $0.12 \mathrm{a}$ & $0.22 \mathrm{c}$ & $0.18 \mathrm{~b}$ \\
\hline Chlorophyll $\mathrm{a}+\mathrm{b}$ & $0.70 \mathrm{~b}$ & $0.58 \mathrm{ab}$ & $0.49 \mathrm{a}$ & $0.80 \mathrm{c}$ & $0.72 \mathrm{~b}$ \\
\hline \multicolumn{6}{|c|}{ 'White Pearl' } \\
\hline Chlorophyll a & $0.44 \mathrm{~b}$ & $0.41 \mathrm{~b}$ & $0.35 \mathrm{a}$ & $0.47 \mathrm{c}$ & $0.43 \mathrm{~b}$ \\
\hline Chlorophyll b & $0.15 \mathrm{~b}$ & $0.14 \mathrm{~b}$ & $0.11 \mathrm{a}$ & $0.17 \mathrm{c}$ & $0.15 \mathrm{~b}$ \\
\hline Chlorophyll a+b & $0.58 \mathrm{~b}$ & $0.54 \mathrm{~b}$ & $0.45 \mathrm{a}$ & $0.64 \mathrm{c}$ & $0.57 \mathrm{~b}$ \\
\hline
\end{tabular}

${ }^{1}$ Means followed by the same letters do not differ significantly at $\alpha=0.05$ 
The cultivar 'Anna Marie' had the lowest chlorophyll content in leaf fresh matter under white and red fluorescent lamps, whereas cv. 'Blue Star' and 'White Pearl' had the lowest chlorophyll content in leaf fresh matter when forced under green fluorescent light. When comparing the cultivars, it was observed that, irrespective of light colour, the highest chlorophyll con- tent in leaf fresh weight was found in cv. 'Blue Star', whereas 'Anna Marie' was characterised by a significantly lower chlorophyll content.

When forcing hyacinths in pots under artificial light, chlorophyll content in leaf dry matter, similarly to chlorophyll content in leaf fresh matter, was dependent on light colour and the cultivar (Table 5).

Table 5

Effect of fluorescent light colour on chlorophyll content in leaf dry weight of three hyacinth cultivars

\begin{tabular}{|c|c|c|c|c|c|}
\hline \multirow{2}{*}{$\begin{array}{l}\text { Chlorophyll content } \\
\text { in leaf dry weight }\end{array}$} & \multicolumn{5}{|c|}{ Light colour } \\
\hline & White & Blue & Green & Yellow & Red \\
\hline \multicolumn{6}{|c|}{ 'Anna Marie' } \\
\hline Dry weight (\%) & $6.75 \mathrm{a}^{1}$ & $6.27 \mathrm{a}$ & $6.30 \mathrm{a}$ & $6.24 \mathrm{a}$ & $6.53 \mathrm{a}$ \\
\hline Chlorophyll a $\left(\mathrm{mg} \times \mathrm{g}^{-1}\right)$ & $3.80 \mathrm{a}$ & $5.75 \mathrm{c}$ & $5.01 \mathrm{~b}$ & $6.06 \mathrm{c}$ & $3.65 \mathrm{a}$ \\
\hline Chlorophyll b $\left(\mathrm{mg} \times \mathrm{g}^{-1}\right)$ & $1.00 \mathrm{a}$ & $1.73 \mathrm{c}$ & $1.45 \mathrm{~b}$ & $1.97 \mathrm{c}$ & $0.94 \mathrm{a}$ \\
\hline Chlorophyll $\mathrm{a}+\mathrm{b}\left(\mathrm{mg} \times \mathrm{g}^{-1}\right)$ & $4.59 \mathrm{a}$ & $7.28 \mathrm{c}$ & $6.25 \mathrm{~b}$ & $7.90 \mathrm{c}$ & $4.40 \mathrm{a}$ \\
\hline \multicolumn{6}{|c|}{ 'Blue Star' } \\
\hline Dry weight $(\%)$ & $6.16 b$ & $5.95 \mathrm{ab}$ & $5.74 \mathrm{a}$ & $6.01 \mathrm{ab}$ & $5.71 \mathrm{a}$ \\
\hline Chlorophyll a $\left(\mathrm{mg} \times \mathrm{g}^{-1}\right)$ & $8.17 \mathrm{~b}$ & $7.38 \mathrm{ab}$ & $6.70 \mathrm{a}$ & $9.16 \mathrm{c}$ & $8.97 \mathrm{c}$ \\
\hline Chlorophyll b $\left(\mathrm{mg} \times \mathrm{g}^{-1}\right)$ & $3.13 \mathrm{~b}$ & $2.50 \mathrm{a}$ & $2.14 \mathrm{a}$ & $3.90 \mathrm{c}$ & $3.54 \mathrm{~b}$ \\
\hline Chlorophyll $\mathrm{a}+\mathrm{b}\left(\mathrm{mg} \times \mathrm{g}^{-1}\right)$ & $11.31 \mathrm{~b}$ & $9.71 \mathrm{a}$ & $9.62 \mathrm{a}$ & $13.38 \mathrm{c}$ & $12.58 \mathrm{~b}$ \\
\hline \multicolumn{6}{|c|}{ 'White Pearl' } \\
\hline Dry weight (\%) & $6.56 \mathrm{~b}$ & $6.11 \mathrm{ab}$ & $5.94 \mathrm{a}$ & $6.21 \mathrm{ab}$ & $5.74 \mathrm{a}$ \\
\hline Chlorophyll a $\left(\mathrm{mg} \times \mathrm{g}^{-1}\right)$ & $6.69 \mathrm{~b}$ & $6.79 \mathrm{~b}$ & $5.92 \mathrm{a}$ & $7.61 \mathrm{c}$ & $7.52 \mathrm{c}$ \\
\hline Chlorophyll b $\left(\mathrm{mg} \times \mathrm{g}^{-1}\right)$ & $2.32 \mathrm{~b}$ & $2.21 \mathrm{~b}$ & $1.86 \mathrm{a}$ & $2.76 \mathrm{c}$ & $2.58 \mathrm{~b}$ \\
\hline Chlorophyll $\mathrm{a}+\mathrm{b}\left(\mathrm{mg} \times \mathrm{g}^{-1}\right)$ & $8.90 \mathrm{~b}$ & $8.81 \mathrm{~b}$ & $7.55 \mathrm{a}$ & $10.33 \mathrm{c}$ & $9.94 \mathrm{c}$ \\
\hline
\end{tabular}

${ }^{1}$ Means followed by the same letters do not differ significantly at $\alpha=0.05$

Under fluorescent yellow light, the contents of chlorophyll $\mathrm{a}, \mathrm{b}$ and $\mathrm{a}+\mathrm{b}$ were the highest in all the three cultivars selected for the study. In cv. 'Anna Marie', the chlorophyll content was also high under blue light. In 'Blue Star' and 'White Pearl', a high chlorophyll content was found in leaf dry weight collected from plants forced under red fluorescent light. In cv. 'White Pearl', a high chlorophyll $\mathrm{a}+\mathrm{b}$ content was found in leaf dry matter of plants forced under red light lamps. The lowest chlorophyll content was observed in leaf dry weight collected from cv. 'Anna Marie' plants forced under white and red lamps, while in 'Blue Star' and 'White Pearl' it was from plants forced under green colour lamps. In cv. 'Anna Marie', light colour had no effect on leaf dry matter. In 'Blue Star' and 'White Pearl', this parameter had the highest value after treatment with white colour lamps; however, it did not differ significantly from the leaf dry matter of plants forced under blue and yellow light.

\section{DISCUSSION}

Light requirements for photosynthesis in bulbous plants are small mainly due to the fact that most of the essential nutrients are accumulated in the bulb. Only small amounts of light are necessary for obtaining the proper appearance of plants through photomorphogenesis $[10,16]$.

Jerzy [17] proved that in the standard method of tulip forcing a very low light intensity of $250 \mathrm{~lx}$ $\left(3 \mu \mathrm{mol} \times \mathrm{m}^{-2} \times \mathrm{s}^{-1}\right)$ and day length of $6 \mathrm{~h} \times \mathrm{d}^{-1}$ are sufficient for 12 tested cultivars. A 1,000 lx $(12.5 \mu \mathrm{mol}$ $\times \mathrm{m}^{-2} \times \mathrm{s}^{-1}$ ) light intensity was more favourable only for $5^{\circ} \mathrm{C}$ forcing. In the conducted experiment, red light colour resulted in the shortening of the forcing period. Suh [3] concluded that light colour or even complete darkness have no effect on the flowering date in 'Apeldoorn' tulips. The length of the first internode in tulips under blue light was greater when compared with the control or with plants forced under orange light. Red light, on the other hand, stimulated elongation of the last internode. All light colours had a favourable effect on total shoot length when compared with the control.

In the present experiment, it was impossible to observe shoot elongation in hyacinth due to its specific structure. However, plant height, the inflorescence length and the length of the longest leaf were determined. 
Plant response was dependent on the cultivar. Light colour did not influence the growth of cv. 'Blue Star'. The elongation effect of green, yellow and red light on the length of the longest leaf was observed in cv. 'Anna Marie' and 'White Pearl'. Also yellow and green light had a favourable effect on plant height in cv. 'White Pearl'. In contrast, red light had a favourable effect on inflorescence elongation in this cultivar.

Red light accelerates flowering of narcissi, while blue light retards it. Blue light improves stiffness of the stem and leaves. Moreover, blue light has a favourable effect on the colouring of flowers and leaves. In contrast, red light lengthens stems and flowers. It also reduces stiffness of stems and leaves. White light gives moderate results. Plants exposed to red light are higher than others, are of greater weight and have longer leaves. Plants forced under blue light are shorter, are of lower weight and have shorter leaves $[7,18,8]$. B or ow iak and Korszun $[19,20]$ demonstrated differences in levels of photosynthetic activity parameters between selected grapevine cultivars. Net photosynthetic rate was related to photosynthesis efficiency and stomatal conductance. Similar interdependencies were observed in hyacinths. B orowiak and Korszun $[19,20]$ also found that photosynthetic activity and leaf size were not interrelated. Specific leaf area was also dependent on the cultivar. In hyacinths, the value of SLA was dependent on the cultivar and was highest in the treatment with green and yellow light. The highest values of SPAD and chlorophyll content in leaf fresh and dry matter were also related to yellow colour light. The treatment with yellow light colour resulted in the highest values of SPAD and the highest chlorophyll content in all the selected cultivars.

\section{Acknowledgments}

This work was funded by the Department of Ornamental Plants as part of its statutory activities.

\section{Authors' contribution}

The following declarations about authors' contributions to the research have been made: study conception: MS, MJ, AK; experiment: MS; analyzing data: MS, MJ; writing manuscript: MS, MJ, AK.

\section{REFERENCES}

1. Jerzy M, Krause J. Crocus-forcing in artificial light. Sci Hortic. 1981; 15(3): 263-266. http://dx.doi.org/10. 1016/0304-4238(81)90036-4

2. Nell TA, Barrett JE, de Hertogh AA. Postgreenhouse longevity of rooting room bulbs as flowering potted plants. Acta Hortic. 1992; 325: 175-184.
3. Su h J K. Stem elongation and flowering response of Tulipa cultivars as influenced by bulb cooling, growth regulators and light quality. Acta Hortic. 1997; 430: 101-106.

4. Pis zczek P, Jerzy M. Światło sztuczne jako substytut światła dziennego w zimowym pędzeniu narcyzów. Część I. Efekt długości dnia. Rocz AR Pozn Ogrod. 2000; 32: 23-30.

5. Woźny A, Jerzy M. Wpływ barwy światła na zimowe kwitnienie tulipana. Pr Kom Nauk Rol Biol BTN B. 2004; 52: 375-381.

6. Woźny A, Jerzy M. Wpływ barwy światła na jakość tulipanów pędzonych metodą $+5^{\circ} \mathrm{C}$. Acta Sci Pol Hortorum Cultus. 2004; 3: 3-11.

7. Jerzy M, Piszczek P, Woźny A. Wpływ barwy światła na zimowe kwitnienie narcyzów pędzonych metodą $+5^{\circ} \mathrm{C}$. Zesz Probl Post Nauk Rol. 2005; 504: 111-118.

8. Woźny A, Zalewska M. The effect of the light colour on the growth and flowering of narcissi under long-day and high quantum irradiance conditions. EJPAU. 11(2): \#19.

9. Krzy mińska A. Ozdobne gatunki i odmiany czosnku (Allium L.): analiza genetyczna i mikromorfologiczna: metody pędzenia roślin. Poznań: Wydawnictwo Uniwersytetu Przyrodniczego w Poznaniu; 2008.

10. Gude H, Dijkem a M. The role of light quality in the forcing of tulips and hyacinths and in the propagation of hyacinth bulbs. Acta Hortic. 1992; 305: 111.

11. Gude H, Dijkema M. The effect of light quality and cold treatment on the propagation of Hyacinth bulbs. Acta Hortic. 1992; 325: 157-164.

12. Śmigielska M, Jerzy M. Post-harvest life of hyacinths forced by different colours of artificial light. Acta Sci Pol Hortorum Cultus. 2009; 8: 3-10.

13. Śmigielska M, Jerzy M. Effect of light colour on forced hyacinth. Folia Hortic. 2011; 23(1): 15-19. http://dx. doi.org/10.2478/v10245-011-0003-8

14. Arnon DI. Copper enzymes in isolated chloroplasts. Polyphenoloxidase in Beta vulgaris. Plant Physiol. 1949; 24(1): 1-15. http://dx.doi.org/10.1104/pp.24.1.1

15. Garnier E, Shipley B, Roumet C, Laurent G. A standardized protocol for the determination of specific leaf area and leaf dry matter content. Func Ecol. 2001; 15(5): 688695. http://dx.doi.org/10.1046/j.0269-8463.2001.00563.x

16. Kawa-Miszczak L. Zmiany w poziomie węglowodanów w różnych etapach rozwoju tulipanów. Rocz AR Pozn Ogrod. 2001; 33: 169-170.

17. Jerzy M. Artificial light as a substitute for daylight in forcing of tulips. Acta Hortic. 1980; 109: 105-110.

18. Woźny A, Jerzy M. Effect of light wavelenght on growth and flowering of narcissi forced under short-day and low quantum irradiance conditions. J Hort Sci Biotech. 2007; 82: 924-928.

19. Borowiak K, Korszun S. Wstępne badania aktywności fotosyntezy jednorocznych roślin wybranych odmian winorośli. Biul IHAR. 2001; 259: 179-191.

20. B orowiak K, Korszun S. Investigations of photosynthetic activity parameters in relation to berries yield of selected grapevine cultivars. Nauka Przyr Technol. 2012; 6(1): 1. 


\section{Wzrost i kwitnienie hiacyntów pędzonych w doniczkach przy świetle fluorescencyjnym o różnej barwie}

\section{Streszczenie}

Trzy odmiany hiacynta pędzono pod lampami fluorescencyjnymi emitującymi światło białe, niebieskie, zielone, żółte i czerwone. Rośliny rozpoczęły kwitnienie w pierwszej dekadzie lutego. Okres pędzenia dwóch odmian 'Anna Marie' i 'Blue Star' był najkrótszy pod lampami o świetle czerwonym. Odmiana 'White Pearl' kwitła równie wcześnie pod lampami o świetle czerwonym, białym i niebieskim. Wykazano wpływ barwy światła fluorescencyjnego na indeks zazielenienia liści (SPAD). Aktywność fotosyntetyczna liści zależała od odmiany. I była powiązana z intensywnością fotosyntezy netto jak również jej wydajnością. Specyficzna powierzchnia liści (SLA) była ściśle uzależniona od odmiany. Wskaźnik SLA był powiązany z poziomem intensywności fotosyntezy i jej wydajności. Specyficzna powierzchnia liści była u wszystkich odmian największa pod lampami o świetle zielonym i żółtym. Zawartość chlorofilu w świeżej i suchej masie liści była najwyższa pod lampami emitujacymi światło o żółtej barwie.

Handling Editor: Elżbieta Weryszko-Chmielewska

This is an Open Access digital version of the article distributed under the terms of the Creative Commons Attribution 3.0 License (creativecommons.org/licenses/by/3.0/), which permits redistribution, commercial and non-commercial, provided that the article is properly cited. 